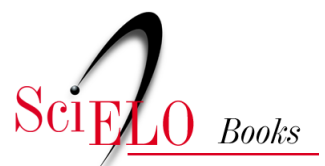

\title{
edvepb
}

\section{Diário De Classe: estudo das postagens de uma aluna de escola pública no Facebook}

\author{
Joana Rodrigues Moreira-Lima \\ Dánie Marcelo de Jesus
}

\section{SciELO Books / SciELO Livros / SciELO Libros}

MOREIRA-LIMA, J. R., JESUS, D. M. Diário De Classe: estudo das postagens de uma aluna de escola pública no Facebook. In: ARANHA, S. D. G., and SOUZA, F. M., eds. Práticas de ensino e tecnologias digitais [online]. Campina Grande: EDUEPB, 2018, pp. 113-142. Ensino e aprendizagem collection, vol. 3. ISBN: 978-85-78795-26-9. http://doi.org/10.7476/9786586221657.0006.

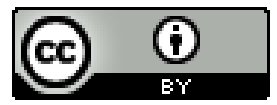

All the contents of this work, except where otherwise noted, is licensed under a Creative Commons Attribution 4.0 International license.

Todo o conteúdo deste trabalho, exceto quando houver ressalva, é publicado sob a licença Creative Commons Atribição 4.0.

Todo el contenido de esta obra, excepto donde se indique lo contrario, está bajo licencia de la licencia Creative Commons Reconocimento 4.0. 


\title{
DIÁRIO DE CLASSE: \\ estudo das postagens de uma aluna de escola pública no Facebook
}

\author{
Joana Rodrigues Moreira-Lima ${ }^{1}$ \\ Dánie Marcelo de Jesus ${ }^{2}$
}

\section{Considerações iniciais}

O crescente acesso de usuários à internet e o surgimento de vários gêneros textuais têm possibilitado mudanças em nossas interações cotidianas. Essas transformações podem, principalmente, ser percebidas em redes sociais, em salas de bate-papo ou em fóruns de discussão

1 Professora do Instituto Federal de Mato Grosso, Campus Sinop. Mestre pelo Programa de Pós-Graduação em Estudos de Linguagem pela UFMT. Atualmente, cursa seu doutorado sob a orientação do professor Dr. Dánie Marcelo de Jesus.

2 Professor do Programa de Pós-graduação em Estudos de Linguagem e do Programa de Pós-Graduação em Estudos da Cultura ambos da UFMT. Tem experiência na área de Linguística Aplicada e Estudos de gênero atuando principalmente nos seguintes temas: discurso em contexto digital, formação de professor, LGBTTI ,diversidades e letramento crítico e inclusão. Foi vice coordenador do GT da ANPOLL ( Associação Nacional de Pós-Graduação e Pesquisa em Letras e Linguística) "Linguagem e Tecnologia" no biênio 2014 a 2016. Foi secretário da ALAB (Associação Brasileira de Linguística Aplicada) entre o biênio 2013 a 2015. É segundo secretário da ANPOLL (Associação Nacional de pós-Graduação e Pesquisa em Letras e Lingüística) entre o biênio 2017 e 2018. 
motivados pela nova ordem espacial e temporal, advinda da manifestação da cibercultura, que altera nossa subjetividade, dando lugar a um existir no mundo por meio das palavras e imagens.

Tais mudanças podem ser denotadas em comunidades virtuais a exemplo do Facebook, que, mundialmente, vem arrebatando jovens e adultos com a finalidade de promover intercâmbio entre os pares ou entre os grupos, criando redes sociais que ligam pessoas com interesses comuns. Para isso, os participantes criam comunidades em torno de diversos temas, intentando reunir o maior número de pessoas que possuam afinidade com o assunto em apreço. Os participantes apresentam suas opiniões sobre determinado assunto. Dessa maneira, as comunidades do Facebook acabam se estruturando, assentadas em diferentes ideologias.

De conseguinte, torna-se ambiente propício à investigação de pesquisadores preocupados com a dinamicidade do ambiente digital e com suas consequências sociais. Essas comunidades também são reveladoras da forma como certos segmentos da sociedade brasileira interagem com determinados temas, sobrelevando a escola. Portanto, ao compreendermos como esses usuários representam certos temas, podemos ter pistas de modo como algumas ideologias são constituídas no pensamento social.

Diante disso, procuramos investigar uma comunidade em particular, "Diário de Classe" -, pertencente a uma aluna do ensino fundamental de uma escola pública de Santa Catarina. Essa comunidade se estrutura em torno do sistema educacional e de suas observações e críticas a esse contexto. Nesse rumo, buscamos entender a materialidade discursiva dessa internauta no âmbito da escola pública. 
A escolha dessa comunidade organizada por uma adolescente se deu por sua popularidade nas redes sociais, tornando-se, sua autora, celebridade midiática, sendo convidada para debater, em diversos eventos no Brasil, a respeito de assuntos como educação, juventude e tecnologia. Criou uma organização não governamental (ONG) com dizeres que anseiam por melhorar a educação do país e, recentemente, publicou um livro desfiando sua experiência vivenciada com o "Diário de Classe". Não bastasse, a ideia de sua comunidade foi replicada por diferentes jovens brasileiros.

Este artigo objetiva, portanto, compreender postagens de uma adolescente em uma comunidade na rede social Facebook. Essas investigações permeiam uma série de trabalhos de caráter interpretativo (ZUBLER, 2014; XAVIER, 2014; ALVES, 2014) a respeito dos efeitos sociais do universo digital na educação, cujo foco é entender como práticas sociais - entendidas como toda experiência social que um sujeito vivencia em suas interações cotidianas -, no ciberespaço, podem edificar enunciados à volta da escola.

Para dar conta desta empreitada, apresentamos, inicialmente, algumas das concepções teóricas oriundas do Estudo do Discurso, tais como a noção de discurso, ideologia, prática discursiva e poder. Já num segundo momento, discutimos o contexto da pesquisa e a análise dos dados. Finalmente, explanamos algumas reflexões que tangenciam esta investigação. 


\section{Discurso e poder}

Não podemos considerar o discurso dissociado de práticas de poder. De acordo com Fairclough (2001, p. 91), o discurso é "um modo de ação, uma forma em que as pessoas podem agir sobre o mundo e especialmente sobre os outros, como também um modo de representação".

Nesse sentido, ao agir sobre o mundo e sobre os outros, o discurso constitui uma das formas de poder. Foucault (1970/2012), a respeito dessa questão, advoga que o discurso não é simplesmente aquilo que traduz as lutas ou os sistemas de dominação, mas aquilo por que se luta, pelo qual se bate, o poder de que nos queremos apoderar.

Portanto, o poder não pode ser visto apenas como algo negativo, mas algo entremeado nos discursos da sociedade, por meio de relações inerentes a cada contexto específico. Isso infere que as práticas discursivas não são neutras, dado que os sujeitos materializam seus discursos para exercer seus diferentes papéis sociais.

Para que esse poder se materialize com sucesso, Fairclough (2001) assevera ser importante que os mecanismos de dominação não sejam evidentes. Essa percepção remete ao fato de que o poder pode ser camuflado, uma vez que ele pode estar embutido em manifestações, cujos argumentos giram em torno de conquistas por interesses comuns (DIJK, 2008).

Para tanto, a linguagem retrata importante componente para as práticas discursivas. No entanto, estas transcendem a língua e suas estruturas quando vistas como práticas sociais. Por isso, Fairclough (2001), ao tecer ênfase sobre o discurso, expressa que este depende da linguagem como prática, e não como atividade puramente 
individual, ou reflexo de variáveis situacionais. Entender o discurso como prática social pressupõe que o poder não é situado em apenas um sujeito ou em uma instituição, como se pensa. O poder é distribuído entre os sujeitos sociais.

Como bem define Foucault (2012), o discurso, como prática de poder, é uma maquinaria complexa e contraditória. Entende-se que ora age com sistemas de exclusão e dominação, ora com vontade de igualdade e democracia. Fairclough (2001), por seu turno, acredita que o discurso contribui para compor as identidades dos sujeitos e suas relações sociais, bem como suas representações sobre o mundo e seus conhecimentos. Assim, esse autor focaliza a relação de poder e a ideologia, constitutivas das dimensões sociais do conhecimento, das relações e da identidade social.

A ideologia, ainda na concepção de Fairclough (2001), está sedimentada em três proposições. A primeira sustenta que a ideologia tem sua existência própria nas práticas das instituições e, por isso, possibilita a investigação das práticas discursivas como formas materiais de ideologia. Para a segunda, a ideologia perpassa o sujeito, constituindo-o. A terceira proposição evidencia que os aparelhos ideológicos do Estado - escola, mídia, igreja, família, etc. - são demarcadores da luta de classe e, em consequência, das lutas no interior do discurso. Partindo dessas três proposições, Fairclough (2001, p. 117) define assim ideologia nestes termos:

significações/construções da realidade (o mundo físico, as relações sociais, as identidades sociais) que são construídas em várias dimensões das formas/ 
sentidos das práticas discursivas e que contribuem para a produção, para a reprodução ou para a transformação das relações de dominação.

As "práticas discursivas" constituem a dimensão do uso da linguagem que engloba os processos de produção, distribuição e consumo dos textos, variando de acordo com os tipos de discursos e fatores sociais. As práticas discursivas guardam um caráter convencional que reedita as condições de produção da sociedade como valores, comportamentos e crenças sociais do mundo capitalista, compondo uma complexa teia de luta de poder, gerador de ideologias diversas que se autoalimentam. Para ele, as práticas discursivas, além do processo convencional ou reprodutor, trazem, em seu interior, a capacidade de transformar as relações de poder com suas respectivas ideologias.

\section{Contexto da pesquisa}

A administradora da página ${ }^{3}$ "Diário de classe", no alto de seus treze anos, principiou suas postagens estudante que era do ensino fundamental de uma escola pública de Florianópolis, em Santa Catarina - e criou sua

3 Em $1^{\circ}$ de maio de 2014, a comunidade possuía 626 mil curtidas. Embora os comentários existentes na comunidade, por parte dessas pessoas, não façam parte deste estudo, percebemos que a maioria dos comentários é de apoio aos discursos da discente, nos quais são observados discursos semelhantes aos dela, referentes à escola. 
página inspirada em uma menina escocesa. Sua postagem centra o foco nos problemas escolares e em assuntos correlacionados com a situação social do país.

A imagem inicial da página pesquisada é representada por algo que nos faz lembrar a figura de um quadro escolar pintado pela cor vermelha, com a função de despertar a atenção aos leitores. Para reforçar essa ideia, as palavras "Diário de Classe", são bordadas com pedaços de giz aludindo às práticas escolares convencionais. A seguir, em destaque a palavra "verdade" sugerindo que, nessa comunidade, o leitor encontrará uma sistemática discussão, mediada pelo diário, sobre a escola.

No respeitante à estrutura da comunidade em destaque, acrescentamos que esse ambiente é composto pela multimodalidade - linguagem verbal e não verbal. A estudante usa bastante texto em suas postagens, contudo as imagens e vídeos aparecem com relevância. Observamos que o celular se tornou instrumento de grande importância para as práticas cotidianas dessa aluna. Consequência disso: a maioria dos registros feitos deriva do próprio aparelho da discente. Em meio às suas postagens, ora surgem registros de fotos das merendas que são servidas diariamente, ora aparecem imagens de problemas estruturais existentes na escola. 


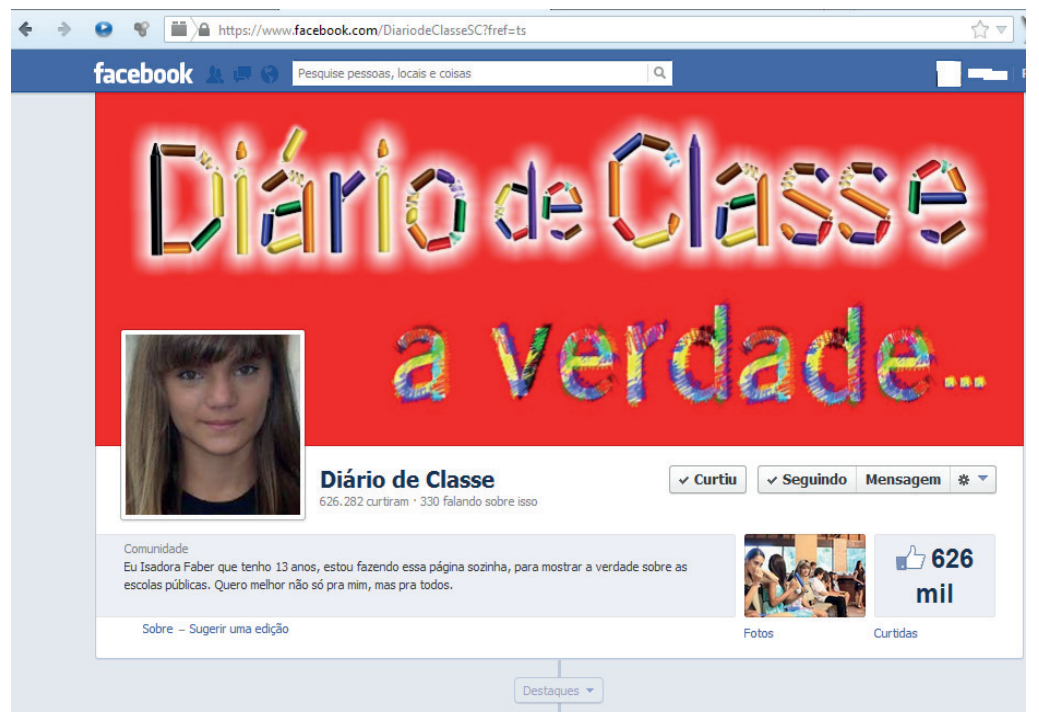

Figura 1: Imagem da página inicial de Diário de Classe

Para compreendermos o discurso sobre a escola pública que ela se afilia em suas postagens, seguimos alguns critérios com vista à sistematização dos dados. Neste intuito, 182 postagens foram analisadas entre julho de 2012 a outubro de 2013, ressaltando um total de 124 foi descartado por repetir seus discursos nas 58 consideradas para tal estudo.

Nessa etapa, os dados foram copiados e colados em páginas de editor de texto com a finalidade de abstrair um panorama e apreender as categorias de análise. Com o objetivo de sistematizar a análise dos dados, decidimos utilizar cores diversas a fim de detectar dados recursivos e significativos para o estudo. Nesse caminho, um recorte de dados foi inspirado em King e Horrocks (2010), realizado por meio da redução do corpus, em forma de frases 
curtas, ideias-chave e conceitos empregados pela aluna. Em seguida, os dados passaram por novo crivo, objetivando identificar os temas mais frequentes.

Neste trabalho, o termo temas implica traços recorrentes e distintos pinçados dos relatos dos participantes, relevantes aos olhos do pesquisador (KING; HORROCKS, 2010). Em razão da natureza desta publicação, traremos, como exemplificador dessa investigação, dois temas: $A$ escola como local da ordem e punição, e a escola ideal.

\section{A análise dos dados}

\section{A escola como local da ordem e punição}

Como retratam diversos pesquisadores (SIBILIA, 2012; FOUCAULT, 1970/2012), a verdade e a punição constituem a maneira de legitimar o discurso, como prática de poder disciplinar existente em âmbito escolar, para manter os corpos dóceis. Diante disso, percebe-se que a escola, em algumas circunstâncias, está situada entre esses dois habitus - a verdade e a punição -, pelos quais seus membros delineiam sua conduta.

A escola ainda busca se pautar em princípios normalizadores com a finalidade de disciplinar os sujeitos escolares. Isso pode ser visto nos excertos a seguir, nos quais a estudante parece reproduzir o redundante discurso hegemônico sobre a escola. 


\section{Excerto 1}

Achei legal...

\section{Ensinam pra gente que a verdade é boa, mas quando dizemos a verdade, todo mundo se ofende.}

Figura 2: Diário de Classe, 12-9-2012

Como se verifica no excerto 1 , a imagem marca um contraste entre as cores preta e branca para realçar o enunciado a propósito da questão relativa à verdade. Haja vista que esta parece depender de quem e de onde vem, para ser legitimada. A imagem selecionada pela estudante tende a questionar os sujeitos escolares que sugerem estar em uma posição privilegiada (professores, direção, coordenação). Esta escolha denota que a escola da discente, como outras instituições sociais - a igreja, órgãos que primam pela justiça, etc. -, também defende, em seus discursos, a primazia pela "verdade", como forma de confissão dos atos, supostamente errados, perante a sociedade. Porém, a verdade advinda destes lócus geralmente obedece a uma hierarquia, em que seu detentor quase sempre é quem se intitula representante soberano.

Ressalte-se que, na atualidade, em que os sujeitos tendem a não obedecer uma única norma, a verdade se torna contingente. Uma vez que esta pode ser certa para alguém, o outro pode com ela não concordar. No entanto, comumente se observa que muitos sujeitos passam boa parte de seu tempo requisitando "sua verdade" ao outro. Se, de alguma maneira, o detentor da verdade for questionado, 
poderão surgir conflitos entre os pares, e até mesmo desestabilizar o lócus de onde ela veio. (FAIRCLOUGH, 2001)

O enunciado acima encarta a concepção binária de que a "verdade é boa", aparentando que isso é o que se espera do outro. Por outro lado, a generalização "todo mundo se ofende" demonstra uma oposição do que era para ser "bom". Talvez, para o contexto mencionado pela estudante, a palavra "gente", anteposta à oração "que a verdade é boa", infira tratar-se dos alunos, e "todo mundo" supõe referir a seus professores. Nesta interpretação, o enunciado atende a seguinte proposição: “Ensinam aos alunos que a verdade é boa, mas, quando dizemos a verdade, os professores se ofendem".

A estudante figura questionar que a verdade não é para todos, nem pertence a todos, depende de quem e de onde é proferida. A verdade professada pelos docentes se inclina a ser boa, mas, ao ser tomada por alunos, para questionar seus superiores, não tem a mesma validade e passa a traduzir algo errado que pode culminar em punição.

Logo em seguida, emerge um exemplo em que a estudante se apropria do discurso da verdade, tomando-o para si. Contanto, a verdade da estudante não aparenta ser a mesma de sua professora.

\section{Excerto 2}

Hoje minha mãe teve que ir ao fórum para uma audiência conciliatória que uma professora auxiliar fez um BO contra ela por injúria. Ficou brava com os comentários do post do dia 20-08 que nas aulas dela não rendiam nada. É verdade, ela dá um texto qualquer e pede pra gente responder duas perguntas, depois a gente fica jogando. 
Se não tem formação para trabalhar com alunos de $7^{\circ}$ série, o que esta fazendo lá? Na audiência, não demorou 15 minutos uma vez que ela não quis nenhuma conciliação, nenhuma retratação, apenas quis seguir em frente com processo crime. Tudo bem, fazer o que, pena que ela apagou os posts dela, mas quem quiser olhar, sobraram as respostas dadas a ela nos comentários.

Diário de Classe, 10-10-2012

A professora, sentindo-se agredida com as postagens da discente, procura leis/justiça para punir a mãe, responsável que é pela educação da filha. Isto reafirma o que Fairclough (2001) insinua, no sentido de que a verdade é contingente, pois aqui parece obedecer a uma hierarquia, haja vista que a palavra "injúria" comprova que a verdade da aluna não era a verdade da professora. Tal fato resultou em conflitos que levaram a docente a tomar atitudes drásticas, sem o intuito de reconciliar-se.

Neste exemplo, subentende-se que a estudante não concorda com a punição proveniente da professora, porque entende que tem razão sobre o fato (É verdade, ela dá um texto qualquer e pede pra gente responder duas perguntas, depois a gente fica jogando). Isso ressalta que os preceitos de punição e de verdade são contraditórios, desconstituídos de validade para aqueles que estão sob este jugo.

Para enfatizar a escola como local de punição, a discente expõe, posteriormente, uma imagem que alude ao fato de que esta instituição educacional guarda semelhanças com confinamentos (SIBILIA, 2012) e que sua função não é, prioritariamente, a aprendizagem. 


\section{Excerto 3}

O portão da escola, os problemas começam na PORTA DE ENTRADA.

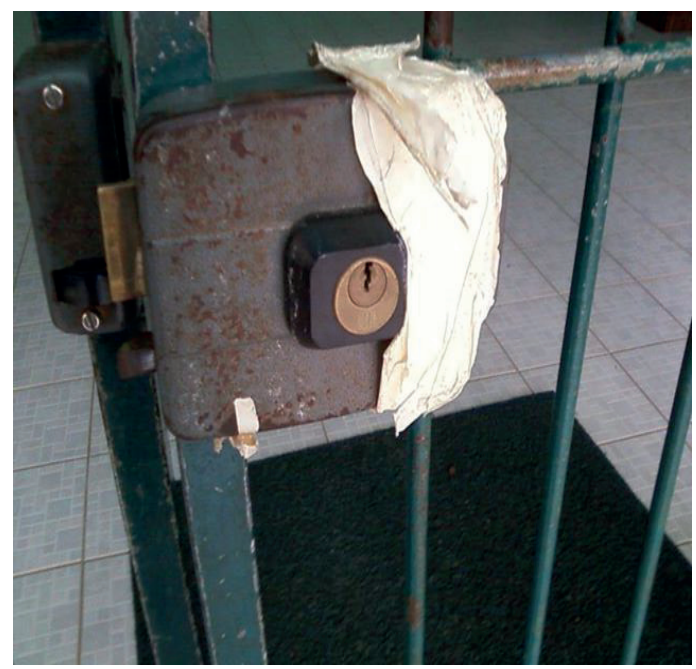

Figura 3: Portão da escola

Diário de Classe, 11-7-2012

Essa imagem do portão sugere uma analogia do que a escola pode representar para alguns estudantes. O que a discente quis registrar, talvez inconscientemente, não é somente a questão de exigir um portão novo para sua escola.

Com base em Foucault (1970/2012), algumas características da escola são peculiares às estruturas arquitetônicas das prisões, cujas salas são construídas lado a lado sem comunicação, janelas com grades, refeitório comunitário, muros altos, portões e vigias. O espaço interno das salas é marcado por carteiras enfileiradas. Já o aluno, uniformizado, se vê sujeito à autoridade do professor. $\mathrm{O}$ 
disciplinamento é refletido pela individualização dos alunos engajados em um espaço quadriculado, em que a postura, os gestos e a produção são monitorados ou vigiados constantemente.

Partindo dessa premissa, a discussão evocada entra em consonância com o que esta aluna, em vários aspectos, forceja por questionar a respeito de sua escola, como espaço de verdade e punição. Ao apresentar o portão de sua escola, que faz alusão ao da prisão, despontam indícios de que a escola, tal como a prisão, agasalha princípios dogmáticos de justiça, expressos pelo desejo de "verdade", que esta pesquisa mostra ser contingentes. Afinal, a verdade doutrinada não pode ser requisitada para quem a profere. Isso abre ensejo a questionarmos se a escola ainda deve ser construída em torno dos pressupostos de verdade?

Por via de consequência, a simbologia do portão, presente nesta figura, remete ao pensamento de que a "PORTA DE ENTRADA" da escola está em concordância com os portões da prisão, os quais também evidenciam seus problemas na porta de entrada, mostrando que ali, naquele espaço, também deve existir vigilância como mecanismo de punição. Ser disciplinado é a forma normalizadora de ser cidadão. Em contrapartida, se as normas não forem obedecidas, cabe ao sujeito transgressor receber a punição.

Entretanto, é válido discutir que o aluno que é educado nestes preceitos disciplinares tende a reproduzir as ações de seu mestre. Isso vem aludir ao pensamento de Fairclough (2001) em relação à ideologia e a seus efeitos de sentido. Por assim ser, no excerto 4, a discente comprova, apesar de contraditoriedades, que está assumindo 
a mesma postura e discurso da escola, conforme se aclara a seguir.

\section{Excerto 4}

Essa página não é contra a escola só que bem agora esta a eleição e estamos mostrando a verdade sobre escolas publicas que não são cenários queremos saber quem vai melhorar isso, quem vai ser responsabilizar de ir ate a escola e cobrar, com que arrume e com que os alunos tenham atenção queremos punição "coisa que é difícil" como falamos da menina que levou a arma. Porque ficar brabo com a verdade estamos querendo o que já era pra ser exigido não por alunos, mais SIM chegou ao ponto que alunas da escola estão exigindo a punição, pra ver onde chegou a coisa.

Diário de Classe, 30-7- 2012

Neste contexto, a estudante parece se colocar, primeiramente, como defensora da escola, cuja função é mostrar a verdade em tempos de eleição. Depois, questiona a ineficiência de sua escola por não oferecer um local adequado para estudar. Para tanto, solicita melhores condições no ambiente em torno, com vista ao comportamento dos discentes. Fica nítida sua posição com referência às palavras "atenção e punição", por meio das quais se justifica a existência do "Diário de Classe", para chamar atenção e mostrar a "verdade", reforçando hábitos disciplinares.

$\mathrm{O}$ advérbio de afirmação "SIM", em destaque, evidencia a desconstrução do papel da escola, por acentuar que, naquele momento, a função de exigir "melhorias e punição" seja competência de alunos, antes de ser da instituição educacional. O discurso desta aluna se deve ao fato de 
que os sujeitos desta geração são performáticos, não possuem apenas uma identidade, mas várias identificações (FAIRCLOUGH, 2001). Esta estudante dá a impressão de se dividir entre o desejo de responder o imaginário de aluna que atende aos pressupostos escolares e o papel de questionadora da escola, que se inclina a tomar o discurso escolar para si. Por sua vez, parece reproduzi-lo sustentado, em muitos aspectos, sob os pilares disciplinares. (SIBILLA, 2012)

Nesse rumo, esta discente, sujeito desta formação educacional, agora também se sente no direito de julgar o que é certo ou errado em sua própria escola e exigir punição daqueles que ela supõe serem culpados. Contudo, paira a dúvida de que a discente não concorda muito com essa atribuição, tomada por ela (aluna), quando deixa implícito que tal está sucedendo em razão de falta de atitude escolar, dado que alunos estão exercendo um papel que não lhes compete. É notório que a estudante se situe como alguém que se apropriou das práticas adotadas pela escola. Isto se confirma nos enunciados, "chegou ao ponto que alunas da escola estão exigindo a punição, pra ver onde chegou a coisa".(Grifo nosso). O termo "alunas", a que se refere, subentende tratar-se dela e de outra colega que, inicialmente, estava dando apoio à sua comunidade.

No excerto 5, a estudante sustenta que sua professora parece tentar coagir não somente a discente, mas também os demais estudantes, como se verifica na sequência:

\section{Excerto 5}

Hoje a professora de português Queila, preparou uma aula pra me "humilhar" na frente dos meus colegas, a aula falava sobre política e internet, ela falava que 
ninguém podia falar da vida dos professores, porque nós podíamos ter feito muitas coisas erradas pra eles odiarem e etc. Eu e acho que a maioria dos meus colegas entenderam o recado "pra mim". Além disso quando vou até o refeitório as cozinheiras, começam a falar de mim, na minha frente e rir, eu e a Melina (minha colega) fomos reclamar com a diretora, então ela disse que eu tenho que aguentar as consequências e que a partir de agora seria assim com todos, não resolveu o problema. Confesso que fiquei muito triste ...

Diário de Classe, 24-8- 2012

Neste enunciado, a estudante assinala que sua comunidade escolar não é, totalmente, incomplacente às normas, ao modo como com ela já expôs, em outra passagem, a respeito de fatos sobre os quais a escola parecia não se manifestar. Neste exposto, a discente expressa toda uma discursividade (FAIRCLOUGH, 2001) para mostrar que ela é a vítima das injustiças escolares. Este fato retoma uma discussão a que já se fez alusão, no tocante ao fato de a escola assemelhar-se a uma prisão. Afinal ela representa o poder disciplinador (FOUCAULT, 1970/2012), onde os transgressores seriam punidos por seus atos. Embora assim, parece ser o local mais envolto por injustiças sociais.

Em sua visão, alguns professores sabem punir aqueles que desejam tomar-lhe a voz. Para isso, a professora preparou a aula para manifestar-se sobre a internet. Supõe que esta explanação tenha sido com o intuito de estabelecer um controle na sala de aula, exasperar uma forma de coerção, para que outros alunos, ao verem os exemplos, não utilizassem a internet para a mesma finalidade. Práticas como estas nos lembram Foucault (1998), que discute sobre os sujeitos excluídos da sociedade (loucos, criminosos), por 
meio dos quais seu discurso era invalidado para enfatizar o saber dos "normais". Diferentemente ocorria com os intelectuais, que traziam em seu discurso a verdade para legitimar seus saberes.

A soberania da instituição escolar se reforça quando a aluna argumenta que não foi somente sua professora que tomou esta postura, considerada coercitiva/silenciadora. Os demais membros escolares (funcionários e diretora) também estão contra a desestabilização escolar, provocada pela estudante. Para isso, na voz da diretora advém o discurso de "aguentar as consequências", endereçado a quem inflige as regras. Mais uma vez, este discurso remete à ideia de justiça/punição, pois, se errou/transgrediu, de algum jeito, deve pagar por seus atos.

Nesse viés, as punições e as práticas de silenciamento parecem não ser mais suficientes, no atual período histórico. As tecnologias digitais trouxeram nova forma de exibição. Quando surgem os discursos dos silenciados, tende a ocorrer uma mistura de discursos, em meio aos quais o poder se torna mais distribuído (FOUCAULT, 1998). A escola precisa pensar em tais questões, haja vista que talvez esta esteja adotando práticas punitivas que ultrapassam as normas escolares, em razão da transposição da sala de aula para as redes sociais, tornando pública qualquer menção que o estudante faz em referência ao professor.

Mas como a escola precisa agir ante estas instabilidades que se instauram na escola?

Sobre esse assunto, continuemos os debates, deixando nítida a posição de alguns docentes acerca da exposição de suas aulas por parte de estudantes, em redes sociais, conforme se vê a seguir: 


\section{Excerto 6}

Hoje eu e meu pai fomos na delegacia porque minha professora de português fez um BO de calunia e difamação. Eu fui, nunca tinha entrado numa delegacia antes, mas lá dentro todos me trataram muito bem mesmo. Estranhei pois para mim o assunto já estava encerrado desde o início do mês quando ela me pediu desculpas, eu aceitei e publiquei, está aqui até agora. Como vocês podem ver, não é fácil manter o Diário no ar.

Diário de Classe,18-9- 2012

Neste exemplo, no respeitante ao excerto 6, não convém discutir se a professora está certa ou errada, pois o que se analisa é o discurso da aluna e, realmente, não se sabe como se deram os fatos que culminaram em tais atitudes. Contudo, pelo que se apresenta na postagem, tende a reiterar as discussões aludidas em outro passo. A estudante comprova que sua desobediência às normas escolares resultou em uma punição, que agora não diz respeito somente à escola.

A professora, percebendo que as regras escolares seriam afáveis para puni-la, procurou outras instituições disciplinares para silenciá-la. Com esse mecanismo de poder (FOUCALT, 1998), a docente quis mostrar que a escola, incompetente para impor-lhe o silêncio, recorria ao sistema judiciário para esboçar tal corretivo tendente a voltar à normalidade. Parece existir, neste momento, uma disputa de poder, em que a docente quis patentear que sua voz ainda prevalece e, se a discente foi capaz de se manifestar contra seu discurso, punições mais severas precisariam ocorrer para reverenciar a palavra predominante. 
Em contrapartida, a estudante questiona que as normas parecem ser somente para o discente, pois esta professora não seguiu as regras escolares, conforme evidencia o regimento a seguir:

\section{Excerto 7}

Na última aula, minha professora de português sugeriu que todos os alunos lessem o regimento interno questões 8 e 9 (me parece censura), eu estava olhando em casa e lendo inteiro, então bem abaixo do que ela falou estava uma parte para professores "Sócia Educativa" dizendo que quando algo acontece algo com aluno, tem que encaminhar o caso para MPSC, não sofri nenhuma medida sócia educativa, fui parar direto na delegacia mesmo. Acho que ela deveria ler o regimento também.

Diário de Classe,18-9- 2012

No excerto 7, a discente comprova que a escola possui o regimento que precisa ser obedecido pelo aluno. Todavia, a aluna argumenta que, no regimento, também há alguns critérios para orientação dos docentes, porém sua professora não seguiu as regras corretamente e, de pronto, resolveu tomar providências mais rigorosas. Este ato da docente reflete que, mesmo a escola tendo suas medidas, estas não são consideradas suficientes pelos professores para ampará-los quando se sentem lesados por alguma atitude de alunos. A ilusão de muitos é que as instituições encarregadas de moldar os sujeitos (manicômio, prisão, justiça) consigam êxito para reprimir-lhes os corpos. No entanto, Foucault (1998) exemplifica com o sistema prisional, assegurando que este não mais desempenha sua função de educar e docilizar os corpos. 
Esse insucesso em projetos que tendem a modelar os sujeitos pode decorrer da imposição de regras sem negociações. É possível discutir, no caso da escola, que, quando se vive sob a pressão dela, a tendência de alguns é querer quebrar as normas impostas, de cuja elaboração não tiveram participação. Fica explícito, na parte destacada do regimento, que o objetivo da docente era usar métodos coercitivos para calar os alunos, consistindo em violência simbólica (BOURDIEU, 1989). Com esta prática, a professora não demonstrou interesse em que os discentes conhecessem ou debatessem todo o regimento, antes que pudessem apenas conhecer a parte que era conveniente a ela.

Pode ser possível que as leis estabelecidas por determinadas escolas já não estejam dando conta de atender o público escolar porque ainda busca desconsiderar a voz do estudante. Talvez tenha chegado a hora de ambos (aluno e professor) dialogarem e estabelecerem suas regras de forma coletiva, sem impor hierarquias aleatórias. Tapscott (2010, p. 159) aduz que "os professores precisam sair do palco e começar a ouvir e a conversar, em vez de apenas falar". Esta afirmação pressupõe que alguns professores não podem ficar tão distantes de seus alunos, mantendo posições assimétricas que parecem não mais combinar com a atualidade. A escola precisa entender que não é constituída apenas por docentes, mas por alunos que possuem anseios próprios. Portanto, nada é mais coerente que as normas sejam negociadas entre seus membros.

Para dar continuidade sobre o discurso da discente do "Diário de Classe", enfatizo, na sequência, a próxima categoria, que encarta alguns debates significativos para 
indicar como esta estudante tende a construir seu discurso, na página do Facebook, em torno da escola ideal.

\section{A escola ideal}

Ao abrir nossas interpretações, percebemos que os discursos existentes nessa categoria estão intimamente ligados a uma escola idealizada para contemplar algumas visões a respeito de como deveria ser o processo de ensino e de aprendizagem e a postura dos professores dele. $\mathrm{Na}$ mesma esteira, a estrutura física ideal para a escola e a solicitação para que a comunidade escolar, principalmente os pais de alunos, mude seu perfil, assentado na passividade, passando a exigir uma escola ideal para seus filhos.

\section{Excerto 8}

Hoje tivemos uma reunião, com a nova professora de matemática Sandra, ela convocou pais e alunos, para irem até lá conhecê-la, fiquei muito satisfeita com ela, parece muito responsável, acho que realmente vamos começar a aprender de verdade, estou muito feliz, espero que todos meus colegas, colaborem.

Diário de Classe, 03-9-2012

No excerto 8, intuímos que a aluna aparenta satisfação com sua nova professora de matemática porque convocou pais e alunos para conhecê-la. Observamos, em um primeiro momento, que a discente promoveu juízos de valor a respeito da professora, esclarecendo que "parece muito responsável". Ao inferir uma qualidade 
para a professora, deduz que, para uma escola ser ideal, necessita ter professores responsáveis.

Logo em seguida, conclama que "acho que realmente vamos começar a aprender de verdade". Desperta-nos a atenção o fato de que, apenas no dia 3 de setembro de 2012, os alunos comecem "aprender de verdade". Assim, a discente parece insinuar que não houvera aprendizagem durante os períodos anteriores. Porém, para que as aulas se tornem satisfatórias, a discente pede a colaboração de seus colegas "espero que todos meus colegas, colaborem". Essa afirmação enuncia que, apesar de ter ela posto a responsabilidade do processo de ensino/aprendizagem nas mãos do professor, este, de sua parte, não é o centro deste processo, pois há os alunos que podem colaborar, ou não, para que haja sucesso.

Portanto, no discurso da discente se afigura que a escola ideal se consolida por meio da primeira opção em que o professor se apresenta como o detentor do conhecimento, e o aluno o receptor, assim como podemos observar a seguir:

\section{Excerto 9}

Hoje quero falar sobre a mudança de comportamento dentro das salas de aula. Na minha aula são 37 alunos. Na maioria das aulas, a turma se comporta direito, faz silêncio, todos podem aprender. Mas em determinada matéria, infelizmente, não é possível aprender. O professor perdeu totalmente o controle da turma. Não consegue ensinar nada, uma bagunça, um barulho, todos falando ao mesmo tempo, fazendo de tudo. Este ano tenho 8 professores, apenas em uma matéria acontece isso. Os alunos são os mesmos, então, o que acontece? Claro que os 
alunos têm sua parcela de culpa, mas e o professor? Será que não tem culpa também? Acho que não adianta o professor saber muito, ter mestrado, se não tem condições de manter a disciplina para ensinar. Deveria ter alguém que assistisse a umas aulas para poder avaliar o potencial do professor. Não é justo com os alunos que querem aprender.

Diário de Classe, 2-4-2013)

A estudante transpira ser defensora de uma escola em que, primeiramente, prevaleça a disciplina "Na maioria das aulas, a turma se comporta direito, faz silêncio, todos podem aprender". Averiguamos, em seus discursos finais, que a escola ideal seja aquela construída de acordo com as conjeturas iluministas (SIBILIA, 2012), sendo a precursora da razão. Papel do aluno é apenas o de receptor do conhecimento legitimado pela instituição escolar, por meio de seus mestres.

Neste excerto, a aluna tece um comparativo entre a aula de alguns professores "Este ano tenho 8 professores, apenas em uma matéria acontece isso". Revelando que a estudante almeja uma aula em que predomine o silêncio, expressa que o professor não consegue ensinar por causa da bagunça e do barulho. A aluna faz referência aos alunos, mas acaba responsabilizando o professor pelos acontecimentos na sala de aula "mas e o professor? Será que não tem culpa também?". Outra evidência apresentada é que a escola ideal não precisa ter professor apenas qualificado. Ela esclarece: antes de o profissional ser qualificado, este precisa saber disciplinar seus alunos "acho que não adianta o professor saber muito, ter mestrado, se não tem condições de manter a disciplina para ensinar". 
Nesse sentido, concluímos que a escola ideal, desenhada nos discursos desta discente, aporta sinais de que o professor é o protagonista em uma sala de aula e, se este não conseguir disciplinar seus alunos, de nada vale seu conhecimento intelectual para contribuir com seus estudantes. E, quando ela se refere à colaboração dos discentes, interpretamos que essa palavra, neste contexto, parece ser sinônimo de silêncio.

Notamos que a discente reforça as mesmas idealizações nas estruturas escolares que tendem a ser voltadas para o disciplinamento dos alunos, conforme veremos nesta passagem.

\section{Excerto 10}

Hoje pra quem não sabe, foi o meu primeiro dia de aula, a escola está linda. As salas estão pintadas, ventiladores são novos, o muro da frente pintado, gradearam a entrada, ou seja, a escola está novinha. Agora os alunos tem que fazer sua parte para conservar. (não tirei foto da frente mas amanhã eu tiro ). Quero aproveitar para agradecer a todos vocês que me apoiam, é muito importante para me incentivar a continuar, pois tem muitas escolas que precisam ser reformadas. Obrigada.

Diário de Classe, 18-2-2013

Conforme visto neste excerto é compreensível que alunos desejam uma escola com estrutura física melhor "As salas estão pintadas, ventiladores são novos". Todavia, percebemos que o ideal de escola construída no imaginário tende a cercadas de grades: "gradearam a entrada". Uma escola ideal para a contemporaneidade poderia ser aquela em que as estruturas fossem reinventadas para romper 
os muros da escola, onde os alunos não precisassem ficar sentados, enfileirados, ouvindo apenas o professor falar. Antes, que fosse o sentido da palavra "colaboração" posto em prática para que alunos e professores arquitetassem uma escola menos autoritária, com divisão de poder mais interativa.

Em arremate, entendemos que o pedido de apoio desta discente se resume apenas no consertar/reformar o que já existe, mas não em mudanças que possam ofertar outros sentidos para a educação da atualidade.

$\mathrm{O}$ discurso posterior insere alguns questionamentos e afirmações sobre o papel da sociedade diante dos acontecimentos do país. Porém, a discente exterioriza algumas palavras que nos indicam o que seria uma escola ideal para esta aluna, e o que ela entende ser ideal para outros sujeitos sociais.

\section{Excerto 11}

Dia 16 agora vou fazer 14 anos. Neste último ano foi o que mais aprendi, não só na escola, mas principalmente por tudo que passei, conheci muitas pessoas, troquei muitas experiências, passei a me sentir cidadã. Aprendi a conhecer melhor as pessoas, como elas falam uma coisa e fazem outras, a inveja, a ignorância, a mentira, a falsidade, a maldade. Tem aquelas que sonham em ser musas pois não passam de uma bunda, outros gostam de desfazer de quem tenta melhorar não conseguindo esconder seu despeito, políticos falam o que você quer ouvir e depois não fazem nada. Aprendi também que não importa ser competente e esforçado, pois o que importa é ser protegido do chefe, como o caso da Diretora da escola que nunca fez uma APP, privando a escola de verbas a mais 
de 2 anos e continua na direção, como se tudo tivesse certo. Como querer que a escola melhore se não tem pessoas capacitadas para administrar? Bancar incompetência com dinheiro público é fácil, queria ver uma situação dessas em escola particular. Falam em mudanças, renovação, tudo que precisa para se eleger e na hora de fazer as mudanças, nada muda. Quem cobra resultados? Quem cobra competência? Quem cobra compromisso? Quem cobra transparência? Estamos no ponto que quem cobra é ameaçado, é apedrejado, é isolado, é o errado, tem que fazer que não viu, que não sabe, não comentar para não se incomodar. O exemplo que vem da minha escola é que a incompetência e má gestão são normais, temos que nos acostumar e não adianta reclamar. Assim se percebe por que o povo se acomoda e aceita tudo que os governantes fazem sem reclamar. Somos treinados desde cedo a perceber que nada muda, que o Brasil é assim mesmo. Eu me nego ser assim. Acredito em mudanças, acredito em pessoas que querem mudar, acredito no Brasil! Vou publicar aqui novamente alguns recursos que as escolas públicas têm direito. Por isso peço a todos que fiscalizem a escola de seus filhos, cobrem, participem, não deixe que prejudiquem os direitos de seus filhos, não facilite.

Diário de Classe, 7-6-2013

Evidentemente, a postagem encarta várias representações em seu discurso. Embora entendamos serem questões relevantes para discussão, centramos nosso foco na compreensão da aluna a respeito de uma escola ideal. A postagem nos remete à interpretação de que a cultura brasileira é de um povo passivo que não cobra qualidade na educação. Ela sugere que esta cultura de passividade está arraigada no povo brasileiro, a ponto daquele que 
realiza cobranças "ser ameaçado, apedrejado, isolado, ser o errado, ter que fazer que não viu, que não sabe, não comentar para não se incomodar".

Ao fazer essa declaração, a aluna traz à tona o fato de esperar que a sociedade, neste caso a comunidade escolar, seja participativa, ao modo como ela está sendo, ainda que ocorram problemas semelhantes aos que ela esteja enfrentando.

Como em qualquer arena social, a palavra é disputada pelos indivíduos para assumir um poder. Aquele que a domina, ou pelo menos pensa que o faz, desempenha um papel de liderança. Por força disso, no excerto, vemos a aluna, desta pesquisa, lutando para ocupar um espaço que ela deseja - o direito de poder criticar o dizer do outro. Assim, em várias passagens da análise, a postagem da discente se revelou contraditória. Anteriormente, houve indícios de que ela preferia uma escola em que o aluno ouvisse o professor e, nesta postagem, conclama ao fato de que os sujeitos escolares sejam participativos.

Parecem-nos distantes essas duas visões, pois, de certa forma, ela não aceita ser uma pessoa que concorda com os fatos recorrentes, conforme demonstra em seu dizer: "Somos treinados desde cedo a perceber que nada muda, que o Brasil é assim mesmo. Eu me nego ser assim". Esse pensamento induz acreditarmos que a escola ideal é aquela em que os sujeitos sabem de seus direitos, conhecedores de quais recursos podem beneficiar as estruturas escolares, de acordo com suas representações sociais de melhoria já discutidas.

Esta contradição aparente, no dizer da aluna, pode entrar em consonância com o que Fairclough (2001), baseado em Foucault (1970/2012;1998), argumenta no sentido 
de que o poder não se apresenta inteiramente em um único lugar ou nas mãos de apenas um sujeito. Dito de outra forma, o poder parece não estar centralizado somente na escola - instituição considerada detentora do poder/saber por longos tempos (SIBILIA, 2012) -, tampouco somente nos alunos. A tendência da contemporaneidade é que os sujeitos vivenciem práticas de poder com seus diferentes mecanismos, de tal sorte que se tenham hierarquias ora mais verticais, ora mais horizontais.

\section{Considerações finais}

Ao longo deste texto, buscamos analisar o discurso de uma aluna responsável pela organização da comunidade "Diário de Classe", do Facebook. As escolhas lexicais apresentadas na materialidade linguística evidenciaram como a adolescente caracterizava a "realidade escolar" em seus textos. Percebemos que o discurso da aluna está sedimentado na concepção de uma escola disciplinadora, percepção forjada ao longo de nossa história de escolaridade. Assim, como vimos, as opções de palavras ou frases não nascem de um acaso, antes estão diretamente relacionadas com processos sociais e culturais mais amplos. (FAIRCLOUGH, 2001)

Esses processos decorrem de nossa interação com o outro, que tece os fios delicados das redes sociais que nos alimentam e constituem nossas práticas discursivas, que, em muitos casos, não são conscientes. Isso não quer dizer que somos mero fruto do meio ambiente, como acreditavam alguns romancistas naturalistas, mas nossa capacidade de pensar e agir é constituída socialmente. 


\section{•Referências}

ALVES, E.C.A. 2014. Fanfiction e aprendizagem da escrita na internet. Cuiabá, MT. Dissertação de Mestrado. UFMT, $100 \mathrm{p}$.

DIJK, T. A. V. Discurso e poder. DIJK, T. A. V. \& HOFFNAGEL, K. F. (orgs.) São Paulo: Editora Contexto, 2008.

FAIRCLOUGH, N. Discurso e mudança social. Trad: Izabel Magalhães, Brasília: Ed.UNB, 2001.

KING, N. \& HORROCKS, C. Interviews in qualitative research. Londres: Sage, 2010.

FOUCAULT, M. A ordem do discurso: aula inaugural no Collège de France, pronunciada em 2 de dezembro de 1970. 22. ed. São Paulo: Edições Loyola, 2012.

M. Microfísica do poder. Trad. Roberto Machado. Rio de Janeiro: Graal, 1998.

SIBILIA, P. Redes ou paredes: a escola em tempos de dispersão. Trad. Vera Ribeiro. Rio de Janeiro: Contraponto, 2012.

ZUBLER, E.P. 2014. Nas águas da tecnologia digital: os dizeres de um grupo de professores. Dissertação de Mestrado. UFMT, $140 \mathrm{p}$.

XAVIER, P.A.M. 2014. A ostra se abriu: percepções de alunos surdos sobre seu processo de aprendizagem de língua inglesa em um curso a distância. Dissertação de Mestrado. UFMT, $100 \mathrm{p}$. 